\title{
Emission of Greenhouse Gases by Hydropower Reservoirs in Afghanistan
}

\author{
Mohammad Anwar Shareefy, \\ Assistant Professor at Parwan University, Afghanistan
}

Doi: 10.19044/esj.2019.v15n15p336 URL:http://dx.doi.org/10.19044/esj.2019.v15n15p336

\begin{abstract}
Studies show that hydropower reservoirs produce 35-70 times more greenhouse gas (GHG) when compared to thermal power plants. The emissions not only depend on the type of eco-region in which the reservoir is located but also on the reservoir characteristics and water quality parameters. This paper explains the emission of greenhouse gases of hydropower reservoirs in Afghanistan. This paper focuses on the introduction and explanation of the main factors for the production of carbon dioxide $\mathrm{CO}_{2}$ and methane $\mathrm{CH}_{4}$. This indicates, how much or how large, the quantity of greenhouse gases which are produced by hydropower reservoirs when compared to other sources of greenhouse gas emissions in Afghanistan. In addition, this paper includes the results of emissions of greenhouse gases of the Noghlu power dam in the Surobi district of Kabul. The Noghlu power dam has not been cleaned up in the last thirty years. It has deposited up to 15 meters of animal, vegetable, and trash. The deposits of these years have reached up to hundreds/thousands of ton. All the animal, vegetable, and trash materials that are transferred by the Kabul River from the Kabul city, from Maidan Wardak and Logar provinces by the Logar River, from Punjshir, Parwan, and Kapisa provinces through the Punjshir River, from Tagab and Alasai districts through the Tagab River are all transferred and settled in the Noghlu dam. As a result, these materials are converted to greenhouse gases of carbon dioxide and methane through aerobic and anaerobic oxidation.
\end{abstract}

Keywords: Methanotrophic, Dam, Oxycline, Biogeochemistry, Aerobic and Unaerobic bacteria, Greenhouse gas

\section{Introduction}

The main reason for the production of methane $\mathrm{CH}_{4}$ and carbon dioxide $\mathrm{CO}_{2}$ in the electric reservoirs is the distribution of organic material which is brought into the bottom of the hydroelectric power station by rivers during the flood events. The organic material originates from the region 
where the source of these gases is in the hydroelectric power station and rivers.

Greenhouse gases reach the atmosphere of a water reservoir or rivers from different ways. When the water passes through the turbine, it releases a lot of gases. The procedure of methanotroph causes the reduction of methane. When compared to thermal power plants, the hydroelectric power plants add and generate more greenhouse gases to the environment. Hydroelectric reservoirs, especially those in the tropics, are an important human source of greenhouse gas emissions.

In this paper, hydroelectric power plants which are more involved in environmental pollutions in Afghanistan are presented with pictures. There are also factors that have transformed these power suppliers into more dangerous producers of greenhouse gases than any other sources of greenhouse gas emission. This is as a result of incuriosity of people living in proximity of these power stations and lack of attention from the government officials. Another cause of this is the lack of public awareness on urbanization. Therefore, this paper aims to provide solutions which will help in reduction of greenhouse gas emission.

\section{First: Afghanistan's Hydroelectric Power Plant}

In the midst of Mohammad Zahir Shah's kingdom (1960-1966), surveys began on the energy sources of Afghanistan. This includes the construction of dams in order to produce electricity and other sources of electricity like oil and gas. These sources of electricity include: Mahiper, Sarobi, Naghlu, Kajaki, Daronta, Jabal Saraj, Parwan Power Plant, Pul-eKhumri, Mazar-e-Sharif power and fertilization industry, Sarde Dam, and Chak dam to name a few.

Afghanistan's hydroelectric power plants include the following:

- Naghlu dam in Kabul province

- Qargha dam in Kabul province

- Shah wa Arus dam in Kabul province

- Sarobi dam in Kabul province

- Mahiper dam in Kabul province

- Daronta dam in Nengarhar province

- Band-e-Amir in Bamyan province: A total of six dams are called Band-e-Amir: Band-e-Gholaman, Band-e-Qambar, Band-e-Haybat, Band-e-Zulfiqar, Band-e-Podina, and Band-e-Panirak

- Kajaki dam in Helmand province

- Gereshk dam in Helmand province

- Dehla dam in Kandahar province

- Salma dam in Herat province 
- Sarde dam in Ghazni province

- Sultan dam in Ghazni province

- Chak dam in Maidan Wardak province

- Sar-e-Hawz dam in Baghlan province

- Zenakhan dam in Baghlan province

- The Kunar dam may be completed in the next six years and it will have a capacity of $300 \mathrm{MW}$

- The Manogi dam which is located in the Kunar province will be completed in the next 4 years and it will have a capacity of $1000 \mathrm{MW}$ There are two dams of Afghanistan which are the main causes for emission of greenhouse gases (Arez, 1361).

\section{A) Naghlu:}

This dam is located within $80 \mathrm{~km}$ of Kabul province with a capacity of 100 megawatts, and it is considered to be the major source of power production. Its height is $110 \mathrm{~m}$ and it is $280 \mathrm{~m}$ long with a capacity of $5.5 \cdot 10^{8} \mathrm{~m}^{3}$.

The Naghlu dam was built during 1960-1968 by the Soviet Union over Punjshir and Kabul rivers in the Sarobi district of Kabul province. The main goal of building this dam is for the production of electric energy. The Naghlu dam has 4 turbines. Thus, each turbine has a capacity of $25 \mathrm{MW}$ and a total capacity of $100 \mathrm{MW}$.

This power reservoir is built with a length of $280 \mathrm{~m}, 110 \mathrm{~m}$ height, and with a storage capacity of 550 million cubed meters of water. Perhaps the Naghlu power station could generate electric power for the five next years. However, the severe crisis in the decrease of water storage capacity is threatening the electricity supply of this dam. The serious challenges that are facing the Naghlu dam include the risk of lack of power generation in the next few years and the sediments that has been deposited at the bottom of the Naghlu dam over the past 30 years. While designing a hydroelectric power plant, the drainage system is built at the same level as the bowl of the dam in order to discharge the dirt and deposits. The excessive materials that are collected in the bowl will empty continuously over time by the drainage system of the dam. This helps to protect the storage capacity of water in the bowl. This is in addition to saving the turbine screens from damage.

The Naghlu power station also has a drain bowl as its drainage system. Nevertheless, for the past 30 years, the drainage system of the bowl sediments has been inactive, and the sediment has not been discharged.

Recently, World Bank prepared an Emergency Power Rehabilitation Project (EPRP), and international experts on hydroelectric power plants have 
conducted a study on the deposits of the Naghlu dam. According to this study, $40 \%$ of Naghlu dam's bowl is occupied with sand and dirt (Sabaoon, 1396).

The Kabul River is one of the sources of the Naghlu power Dam which are connected in the city of Kabul with a heavy load of materials. In many months of the year, the Kabul River does not have enough water. Thousands of cubic meters of materials and dirt are stored by people in the seabed (Figure 1). Thus, in the rainy seasons including March, April, and May, all of the wastes of Kabul River are transferred to the Naghlu power plant and it is stored there. In addition, the Logar River transfers animal and plant materials from Maidan Wardak and Logar to the Lugar River during the rainy seasons.

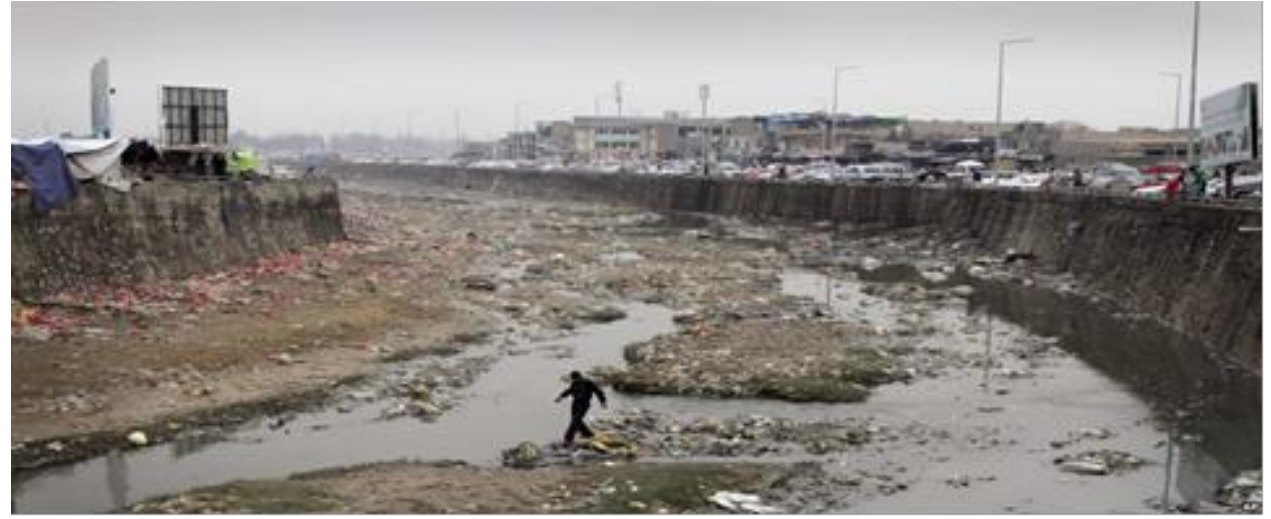

Figure 1. A part of Kabul river

The Punjshir River is one of the most important and permanent sources of the Naghlu dam. The Jabel Saraj, Salang, and Ghorband Rivers are also connected to the Punjshir River. They are connected to the Naghlu dam while moving from Kapisa and Parwan provinces where they transfer animal and plant materials themselves. The Tagab River is connected to the Naghlu dam for three months during the rainy seasons. This river transfers materials including plant materials while moving from the Ala Sai district to Naghlu dam and it is stored there. However, the sediment deposits in the Naghlu dam have reached its critical climax. 


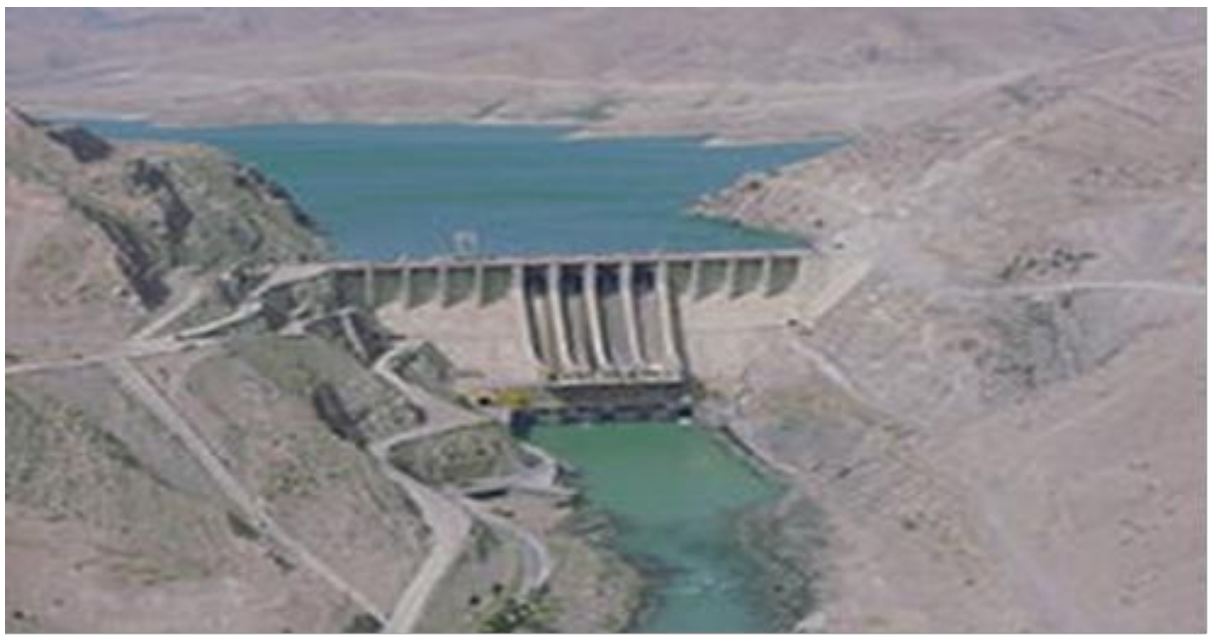

Figure 2. Naghlu dam

\section{B) Kajaki Dam:}

This dam is in Helmand province which is $161 \mathrm{~km}$ to the northwest of Kandahar with an area of $1800 \mathrm{~km}$ square, a height of $100 \mathrm{~m}$, and a length of $270 \mathrm{~m}$. This dam has a capacity of $1.715 \times 10^{9} \mathrm{~m}^{3}$ and it was built during $1951-$ 1953. In 1975, two generators were installed to this dam with a capacity of $16.5 \mathrm{MW}$ by the assistance of USAID. The Kajaki dam has a storage capacity of 640 million cubic meters water, and it is able to produce $42 \mathrm{MW}$ of electricity. The water supplies of the Kajaki power plant originate from areas which transfer animal and plant materials to the dam. This has resulted in the loss of $15 \%$ of water storage capacity in the bowl of the dam due to sediments.

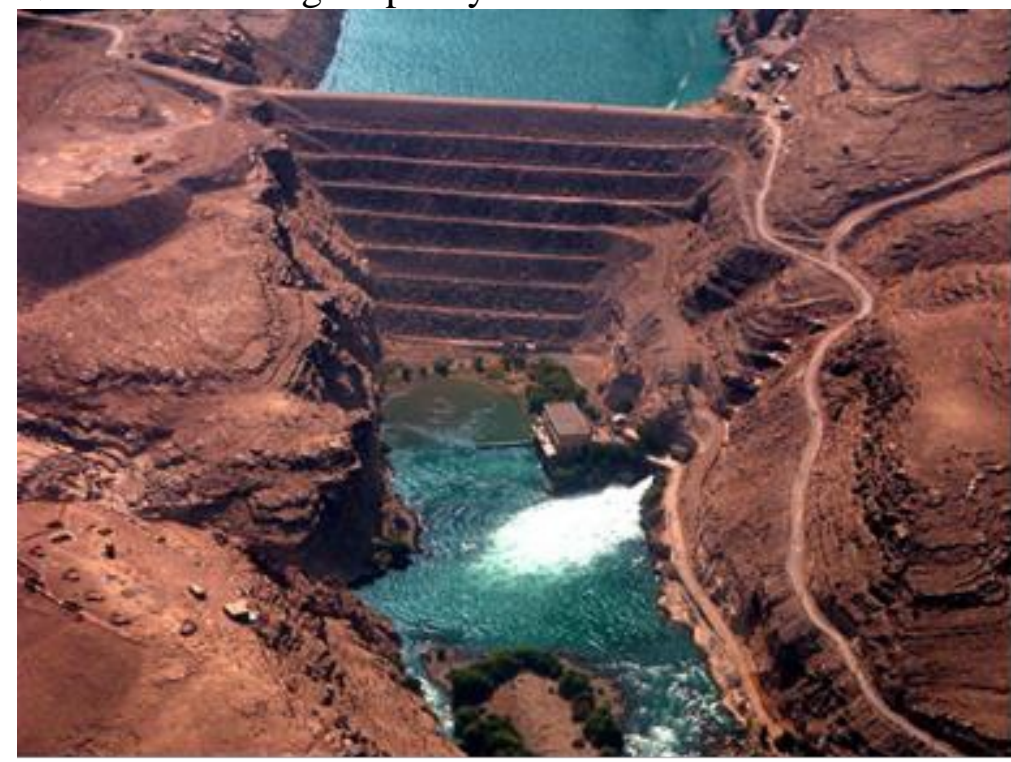

Figure 3. Kajaki dam 
However, through the biological, physical, and chemical processes of the materials with the help of aerobic and anaerobic oxidation, the stored materials of both hydroelectric dams and underwater stores has been converted to greenhouse gases of carbon dioxide and methane. This has more greenhouse effects when compared to the other sources of greenhouse gases, and it is released to the atmosphere.

\section{Second: Emission of Greenhouse Gases by the Hydroelectric Power Plants of Afghanistan}

Recent studies have shown that electricity generated by hydroelectric reservoirs is not considered as neutral energy. This is because forest plants are brought to the reservoirs by floods and then they perish. They are no longer able to absorb carbon dioxide $\mathrm{CO}_{2}$ and the leaves are deposited to the reservoir bed. The bacteria break down the organic material to produce carbon dioxide $\mathrm{CO}_{2}$ in aerobic conditions. These gases can be released into space where they increase human greenhouse gases which leads to global warming. Today, the problem of greenhouse gases and their impact on global warming is an important issue both in science and politics.

Carbon dioxide $\mathrm{CO}_{2}$ and methane $\mathrm{CH}_{4}$ are two important human greenhouse gases. The key to dealing with these two greenhouse gases is that the global warming potential of methane $\mathrm{CH}_{4}$ is 21 times longer than carbon dioxide $\mathrm{CO}_{2}$ over a hundred year period. This means that methane $\mathrm{CH}_{4}$ is much more harmful than carbon dioxide $\mathrm{CO}_{2}$.

Water reservoirs plays an important role all over the world with differences in terms of conditions, latitude, productivity, and the location of water habitat. For example, ice, tropical climate, ways of connecting reservoir storage, flood area, and etc. To explore the earth's biochemistry, a major focus is on a reservoir. For example, the Naghlu power plant and the images of the two other power plants (Sarobi Kabul and Kajaki Helmand) can be viewed in this paper.

\section{Third: The Emission of the Two Important Greenhouse Gases: Carbon dioxide and methane $\mathrm{CH} 4$ in Afghanistan}

Emissions of greenhouse gases from hydroelectric power plants vary according to the characteristics of each hydroelectric power plant. Greenhouse gases of hydroelectric power stations are less produced in dry areas than the wet areas. About $90 \%$ of the total greenhouse gases of methane and $40 \%$ carbon dioxide are released from the reservoirs of the wet areas.

The emission of carbon dioxide $\mathrm{CO}_{2}$ gases is higher than methane $\mathrm{CH}_{4}$ in both dry and wet areas. As can be seen, the emission of methane $\mathrm{CH}_{4}$ and carbon dioxide $\mathrm{CO}_{2}$ is much higher in warm places than the cold ones. This is 
in addition to the greater difference in the emission of greenhouse gases in different regions. Weather changes in the area of a reservoir can also have a significant effect on greenhouse gas emissions (Noristani, 1350).

\section{Methane Oxidation}

The most important product of methane oxidation is the methanotrophic bacteria oxidation. In fact, the global warming potential of methane $\mathrm{CH}_{4}$ is more than carbon dioxide $\mathrm{CO}_{2}$ because of the amount of carbon dioxide that is converted into mineral rocks. This is one of the positions of a power plant where the oxidation of methane happens in its oxyclyne. Hence, methane by reaching the Oxic conditions is released to the top where the methanotrophic bacteria exist. These bacteria are stained with methane, and it is oxidized to receive oxygen for referral energy.

$$
\mathrm{CH}_{4}+2 \mathrm{O}_{2} \rightarrow \mathrm{CO}_{2}+2 \mathrm{H}_{2} \mathrm{O}
$$

Another position for methane oxidation is the sediments where there is enough oxygen available. This is the reason why the places including under the lakes, the water in the lowest layer of the nonfreezing lakes, are cold and have a low amount of oxygen. This is where the reaction of methane oxidation takes place. For this reason, carbon dioxide is used for its first product under the lake such as the dive of carbon dioxide.

Researches have recently been made by the International Committee on Climate Change (IPCC) on the use of methane and carbon dioxide. Based on this assessment, the effect of methane in global warming is 72 times higher than carbon dioxide over the course of 20 years which is 25 times more in the period of a hundred years. The Global Warming Potential (GWP) by the IPCC has proven that the one-year-long methane radiation from a large power plant affects the warming of a hundred years. This is equal to 2.6 billion tons of carbon dioxide.

The methane oxidation happens with the help of methanotrophic bacteria. Equation (1)

With the help of genetic bacteria, the methane combines with glucose and carbon dioxide.

$$
3 \mathrm{CH}_{4}+3 \mathrm{CO}_{2} \rightarrow \mathrm{C}_{6} \mathrm{H}_{12} \mathrm{O}_{6}
$$

As a result of decomposition under the Oxic conditions, glucose converts to carbon dioxide, water, and energy.

$$
\mathrm{C}_{6} \mathrm{H}_{12} \mathrm{O}_{6}+6 \mathrm{O}_{2} \rightarrow 6 \mathrm{CO}_{2}+6 \mathrm{H}_{2} \mathrm{O}+\mathrm{E}
$$


Decomposition takes place in the absence of air or non Oxic with the help of nonaerobic bacteria or methanogenetic. The following reaction of methanogenesis happens:

$$
\mathrm{C}_{6} \mathrm{H}_{12} \mathrm{O}_{6} \rightarrow 3 \mathrm{CH}_{4}+3 \mathrm{CO}_{2}
$$

The methane produced by methanogenesis is transformed again into water and carbon dioxide, equation (1) (Kohistany 1395).

Some other factors, such as $p H$ physical and chemical parameters of water in a hydroelectric power plant, also play an important role in greenhouse emissions and its release to the earth's atmosphere. Under the aerobic conditions in a hydroelectric power plant, gases such as the Nitrous oxide or laughing gas $\mathrm{N}_{2} \mathrm{O}$ can also be produced. Nitrous oxide or laughing gas $\mathrm{N}_{2} \mathrm{O}$ is another greenhouse gas which can also be emitted to the atmosphere. In this paper, more explanation has not been given due to unavailable required statistics about nitrous $\mathrm{N}_{2} \mathrm{O}$ (Bahram 2007).

In addition, all the soft organic materials which are stored at a great quantity at the bottom of Naghlu power plant are dissolved by bacteria as long as oxygen exists there and they produce carbon dioxide. In the lower layer of the non-frozen lakes (hypolimnion), other oxidants are used instead of oxygen such as nitrate ion $\mathrm{NO}_{3}^{-}$, Iron (III)ion $\mathrm{Fe}^{3+}$, sulfate ion $\mathrm{SO}_{4}^{2-}$, and carbon dioxide $\mathrm{CO}_{2}$. On the other hand, on the surface layer of the non-frozen lakes (epilimnion oxic), there is dissolved oxygen which can oxidize the organic material. In layers of soil, oxidation occurs by the methanogenic bacteria because there is no oxygen in soil layers of lakes and power plants. Vegetable materials such as leaves, shrubs, and plants are mainly decomposed in the first three years after flooding. Vegetable materials with high cellulose levels such as tree trunks (boles) are dissolved by microorganisms such as fungi. Thus, the trunks of the tree boles can remain in a hydroelectric power plant for up to 100 years. In addition, water flooding contains a certain amount of organic carbon. This amount of carbon depends on the type of soil and the type of carbon's quality. Due to the fact that the peat saves a large amount of carbon and it is produced in the electric power plants, such soils have a high potential for greenhouse gas emissions in the electric dams (Shirzad 1397).

\section{Conclusion}

Water reservoirs, in addition to their biological effects on the environment, such as the destruction of the flooded area play an important role on greenhouse gas emissions in the air. Water reservoirs have the potential for a lot of greenhouse gas emissions, such as carbon dioxide $\mathrm{CO}_{2}$ and methane $\mathrm{CH}_{4}$ which has a significant contribution to global warming. 
Decomposition of the organic materials is the main reason for emission of greenhouse gases. The importance of different organic material sources can change the age and life of the reservoir. They also depend on the climate of the area in which the reservoir is constructed.

There are many ways in which greenhouse gases are emitted into the environment. Studies show that emissions of greenhouse gases, particularly methane $\mathrm{CH}_{4}$ and carbon dioxide $\mathrm{CO}_{2}$, occurs from the surface of the water reservoirs. In addition, most greenhouse gases are also released in the turbines of a water reservoir where the water flows into the river.

Most importantly, methane $\mathrm{CH}_{4}$ is oxidized by the methanotrophic bacteria which is a key factor in reducing the amount of methane $\mathrm{CH}_{4}$ released to the atmosphere. These are the ways to minimize greenhouse gas emissions in a hydroelectric reservoir. Nonetheless, there is still a need for further research in this area.

The best source of energy is the energy of the sun. The energy of the sun is the first energy source for animals and plants and its energy lasts for an infinite period which does not have any side effects. Also, it does not pollute the environment.

\section{To prevent the emissions of the greenhouse gases, the following steps must be taken:}

The sediment discharge system of the Naghlu power plant must be regenerated and re-activated. The bottom of the reservoir and its sediment must be washed, and the sediments should be regularly discharged and controlled. Due to the proximity of the Naghlu and Sarobi power lines, sediment discharge must be carried out simultaneously on both power lines. A permanent solution must also be chosen for the dust in the Kabul River. If the above items are not carried out within the next five years, the turbine blades of Naghlu power plant will be destroyed by particles of sand and other surplus materials. As a result, the turbine will not be able to work anymore. The storage capacity of the Naghlu bowl will severely decrease, and Naghlu will be converted into the Dipper Dam.

Similarly, the release of two important greenhouse gases, methane and carbon dioxide has also increased. They also produce the most greenhouse gases than any other sources of greenhouse gas emissions, such as thermal power generation, transport, bricks manufacturing, and cement production facilities. 


\section{Recommendations}

1. In Afghanistan, the weather is mostly sunny. Therefore, solar energy is very economical and it can be used since it is free from environmental pollutants.

2. Electric reservoirs should be built in areas where water has not crossed between fields and forests.

3. Metal joints should be used at the seamounts (water sources) while also removing the vegetable and animal materials from the metal joints from time to time.

4. The responsibility of all residents living on the waterway side of these livestock is to refrain from throwing garbage in the rivers.

\section{References:}

1. Arez Ghulam Gailany (1361). General Geography of Afghanistan, Kabul University. pp. 45-78.

2. Bahram Ghulam, M. (2007). Agricultural Program Planning. Kabul University. Kabul University Press. pp. 1-3.

3. Kohistany Nesar Ahmad (1395). Environmental Protection, Kabul University. pp. $105-1021$.

4. Noristany Akbar, M. (1350). General Geography of Afghanistan, Kabul University. pp. 33-42.

5. Sabaoon Naseem, M. (1396). Afghanistan Recognition, $2^{\text {nd }}$ volume, Police Academy of Kabul. p. 27.

6. Shirzad Dawood, M. (1397). Statute of Environment. Kabul University. pp. 15-27. 